\title{
Physicochemical and microbiological properties of yogurt made with microencapsulation probiotic starter during cold storage
}

\author{
EVY ROSSI" , FAJAR RESTUHADI, RASWEN EFENDI, YOSSIE KHARISMA DEWI \\ Department of Agricultural Technology, Faculty of Agriculture, Universitas Riau. Jl. HR Soebrantas Km 12,5, Simpang Baru, Tampan, Pekanbaru \\ 28292, Riau, Indonesia. Tel.: +62-761-63271, •email: evy.rossi@lecturer.unri.ac.id
}

Manuscript received: 3 January 2021. Revision accepted: 27 March 2021.

\begin{abstract}
Rossi E, Restuhadi F, Efendi R, Dewi YK. 2021. Physicochemical and microbiological properties of yogurt made with microencapsulation probiotic starter during cold storage. Biodiversitas 22: 2012-2018. This study's purposes were to characterize probiotic properties, identify strains of K12.1, produce a microencapsulated starter (MS) for yogurt, and evaluate yogurt's microbiological quality during storage refrigerated temperatures. This research was conducted experimentally using isolate was further identified based on 16S rRNA gene sequence analysis. The identified strain and Streptococcus thermophilus were microencapsulated using sago starch and whey isolate protein $(1: 1 \mathrm{w} / \mathrm{w})$ for yogurt starter. The starter was added as much as $1,3,5$, or $7 \%(\mathrm{v} / \mathrm{v})$, then incubated for 18 hours at $37^{\circ} \mathrm{C}$. The best yogurt was evaluated for its microbiological quality at refrigerated temperature for $0,7,14,21$, and 28 days. The results showed that K12.1 isolate with probiotic characteristics was Lactobacillus plantarum VP3.3. The microencapsulation starter concentration affected acidity, total acid, total Lactic Acid Bacteria (LAB), viscosity, and total solids. The use of 7\% microencapsulation starter of Lactobacillus plantarum VP-3.3 and Streptococcus thermophilus gave the best yogurt, with a $\mathrm{pH}$ value 4.36, total lactic acid $0.99 \%$, total LAB $10.00 \log$ CFU mL-1, viscosity $546.37 \mathrm{cP}$, and total solids $10.40 \%$. The total amount of LAB in yogurt stored during cold temperature for 28 days still meets the probiotics standards $(9.98 \log \mathrm{CFU} / \mathrm{mL})$.
\end{abstract}

Keyword: Lactobacillus plantarum, microencapsulation, sago starch, Streptococcus thermophilus, whey isolate protein

\section{INTRODUCTION}

One of the most popular functional foods today is probiotic drinks. This drink contains probiotics in live microbes that have beneficial effects on the host's health (Salminen and Wright 2011). Besides, probiotics can have a physiological impact on health, such as preventing various digestive tract problems (Howarth and Wang 2013), lowering triglycerides (Kassaian et al. 2019). Most probiotics are Lactic Acid Bacteria (LAB), also known as General Recognized As Safe (GRAS), which means microbes are not a health risk (Tadesse et al. 2005). Some of them have probiotic activity, such as LAB isolated from solid waste of soymilk production, K12.1 LAB isolate (Rossi 2018). Several previous studies have isolated LAB from curd (Hawaz 2014), okara (Aritonang et al. 2017), pastirma (Öz et al. 2017), and goat milk (Yelnetty et al. 2020).

Use of probiotics in food has been widely used such as synbiotic ice cream (Aritonang et al. 2019). However, extreme conditions in the digestive tract can reduce its resistance in the intestine so that its physiological function for the host will decrease. To survive in the gut, organisms must be tolerant of the low $\mathrm{pH}$ and bile toxicity prevalent in the small intestine. For colonization, probiotics should exhibit good surface hydrophobicity and aggregation properties (Del Re et al. 2000; Collado et al. 2007). Functionally, by inhibiting toxins' action or production (Hugo et al. 2008) by expressing bacteriocins and inhibiting mucosal surface pathogens' binding (Collado et al. 2006), they can neutralize the effects of pathogens. It may also demonstrate antioxidant and immunomodulatory activities (Vitiñi et al. 2000).

Several studies have reported that probiotics are very sensitive to environmental conditions and have low survivability in the digestive tract (Shi et al. 2012). Factors that can affect probiotics' viability include $\mathrm{pH}$ and bile salt (Rossi et al. 2018). The method used to protect and maintain $\mathrm{LAB}$ resistance in the digestive tract is an encapsulation that forms a layer in a matrix. The inside is spherical in shape like a capsule wall, which covers the encapsulated material (Vidhyalakshmi et al. 2009). The advantage of encapsulation is that it has a semipermeable, round, and strong membrane so that the bacterial cell can survive in extreme conditions. The materials commonly used for encapsulation are various polysaccharides and proteins, such as starch, alginate, albumin, and casein.

The materials used for encapsulation need to be considered because each material has different characters and does not necessarily match the core material to be encapsulated (Desmond et al. 2002). Proteins and polysaccharides are widely used for encapsulating bioactive materials (Maleki et al. 2020). Sago starch (SS) is used as an encapsulation material because of its ability to form a gel when heated (Vamadevan et al. 2013). Sago starch can also be used as a prebiotic ingredient (Zhu 2019). Whey isolate protein (WIP) is also the most widely used encapsulation material. The advantages of WIP as an encapsulation material are that it can form a matrix that can trap $\mathrm{LAB}$ to be protected from extreme environmental 
conditions (Maleki et al. 2020). To increase the protective effect on bioactive against external conditions and under simulated gastrointestinal conditions, two valuable nutrients, LAB and anthocyanins from black beans, were microencapsulated using WPI (Vasile et al. 2020). Besides, until the end of the product's shelf life, probiotic bacteria should remain viable (Tamime et al. 2005; Donkor et al. 2007). The purposes of this study were to characterize probiotic properties and identify K12.1 isolate using $16 \mathrm{~S}$ rRNA, obtain the best level of microencapsulated starter for producing yogurt, and evaluate the microbiological quality of yogurt during storage at $4^{\circ} \mathrm{C}$.

\section{MATERIAL AND METHOD}

\section{Material culture}

Lactic Acid Bacteria isolate (K 12.1) obtained from soybean epidermis was a solid waste making soy milk from the home industry in Tampan District, Pekanbaru. Indonesia. This isolate was chosen because it has the best antimicrobial activity of the other 24 isolates. These isolates were evaluated for their probiotic characteristics. Pathogenic bacteria used were Escherichia coli O157: H7, Listeria monocytogenes, and Staphylococcus aureus ATCC 25923.

\section{Probiotics properties of isolate $\mathbf{L A B}$}

Antimicrobial activity of Lactic Acid Bacteria isolate

Modification of the well diffusion test (Yang et al. 2012) was used to evaluate antibacterial activity against pathogens (E. coli O157: H7, L. monocytogenes, S. aureus ATCC 25923). The cell-free supernatant was grown in MRS broth for 24 hours at $37{ }^{\circ} \mathrm{C}$, under anaerobic conditions, centrifuged at $10,000 \mathrm{rpm}$ for $5 \mathrm{~min}$ at $4{ }^{\circ} \mathrm{C}$. Fifty $\mathrm{mL}$ of cells and cell-free supernatant each were placed in a well where pathogenic bacteria on MHA medium (Mueller Hinton Agar, Merck) grew. The size of the zone of inhibition showing the antibacterial activity of the isolates was measured after 24 hours.

\section{Viability of Lactic Acid Bacteria isolate to acids and bile salt}

A low $\mathrm{pH}(\mathrm{pH} 2$ and 3) resistance of LAB was carried out according to the method described by Shi et al. (2013). Five $\mathrm{mL}$ of MRS Broth solution without and with $\mathrm{pH}$ adjustment of 2 and 3using $\mathrm{HCl}$ in a test tube was inoculated with $1 \% \mathrm{LAB}$ working culture, then shaken until blended. Furthermore, the LAB resistance was observed after the culture was incubated at $37^{\circ} \mathrm{C}$ for 90 and $180 \mathrm{~min}$.

By inoculating $1 \mathrm{~mL}$ of LAB isolate into MRS broth containing 0.3 and $0.5 \%$ bile salts (Sigma), The culture's absorbance at $620 \mathrm{~nm}$ was measured after 0 and $5 \mathrm{~h}$ of incubation at $37^{\circ} \mathrm{C}$. Acid and bile resistance tests were replicated three times each with duplicate analysis.

\footnotetext{
Hydrophobicity of Lactic Acid Bacteria isolate by in vitro

The K12.1 LAB isolates that had the potential as probiotics were observed for their adhesion properties on
}

the intestinal mucosa in vitro (Sánchez-Ortiz and LunaGonzález 2015). LAB cultures in MRS broth were incubated anaerobically at $37^{\circ} \mathrm{C}$ for $18-22$ hours, then centrifuged at $10,700 \mathrm{rpm}$ for $5 \mathrm{~min}$. LAB suspension was added $1 \mathrm{~mL}$ xylene in a cuvette and this suspension was left for 60 seconds. The suspension was then incubated for 2 hours at $37^{\circ} \mathrm{C}$. There was an aqueous phase at the bottom of the cuvette, which is then taken and measured at OD 600 nm (A1). P-xylene was used because the cell surface's hydrophobic or hydrophilic nature was reflected by bacterial adherence to this solvent.

\section{Identification K12.1 Lactic Acid Bacteria isolates using 16S rRNA.}

Based on 16S rRNA gene sequence analysis, the LAB species were further identified. Using kit Presto ${ }^{\mathrm{TM}}$ Mini gDNA Bacteria. The genomic DNA from the K12.1 isolate was extracted. The DNA gene was amplified by universal primers 27 F (5'-GAGTTTGATCCTGGCCTAG-3 '), 1525 R (5'-AGAAAGGAGGTGATCCAGCC-3'). using PCR. The PCR amplification conditions were as follows: initial denaturation for $2 \mathrm{~min}$ at $95 \mathrm{EC}, 40$ denaturation cycles for $45 \mathrm{~s}$ at $94^{\circ} \mathrm{C}$, annealing for $1 \mathrm{~min}$ at $56^{\circ} \mathrm{C}$, extension for 1 min and $40 \mathrm{sec}$ at $72^{\circ} \mathrm{C}$, and final extension for $10 \mathrm{~min}$ at $72^{\circ} \mathrm{C}$. The reaction mixtures were subsequently cooled to $4^{\circ} \mathrm{C}$, and agarose gel electrophoresis with 1 percent agarose was used to analyze the PCR products. The gel was placed in a container plus TBE until submerged. The gel, then seen under a UV lamp. The resulting sequence of isolates was analyzed with BLASTn on the NCBI website. The phylogenetic tree was generated using the Kimura-2parameter model.

\section{Yogurt production using microencapsulation inoculum}

Full cream milk was pasteurized at $85^{\circ} \mathrm{C}$ for $30 \mathrm{~min}$ and cooled rapidly at $45^{\circ} \mathrm{C}$ (Donkor et al. 2006). The microencapsulated starter of Lactobacillus plantarum strain VP-3.3 and Streptococcus thermophilus (ratio 1: 1) was added as much as $1,3,5$, or $7 \%(\mathrm{v} / \mathrm{v})$, then incubated for 18 hours at $37^{\circ} \mathrm{C}$. All the treatments were applied with three replications. The best yogurt made using a microencapsulation starter was evaluated for its microbiological quality at refrigerator temperature for 0,7 , 14,21 , and 28 days.

\section{Encapsulation Lactobacillus plantarum strain VP-3.3}

Harvested L. plantarum strain VP-3.3 and $S$. thermophilus (ratio 1: 1) were microencapsulated with sago starch (SS) and whey protein isolate (WPI). The encapsulation of bacteria was carried out with certain modifications using the method presented by Rajam et al. (2012). Preparation of 1: 1.5 core-to-wall ratio, which walls were sago starch and WPI powder in a ratio of 1: 3. A total of $37.5 \mathrm{~g}$ of SS and WPI were mixed with sterile water to a volume of $150 \mathrm{~mL}$ in a beaker. The solution was heated at $70^{\circ} \mathrm{C}$ and stirred slowly for $15 \mathrm{~min}$ to make it homogeneous. Probiotic cells $(25 \mathrm{~g})$ were added slowly to make uniform cell mixing. The final volume was produced with distilled water up to $210 \mathrm{~mL}$ and further mixed for 5 min. The probiotic bacterial suspension was mixed with the 
wall material solution (1:1 and 1:1.5). The suspension of probiotic bacteria with a wall solution material $(1: 1,5)$ was frozen for 48 hours at $-60^{\circ} \mathrm{C}$, then subjected to freezedrying for 20 hours. The freeze-dried powder was stored at $4^{\circ} \mathrm{C}$.

\section{Analysis Physicochemical and Microbiological characteristics of Yoghurt}

The yogurt $\mathrm{pH}$ was measured using a $\mathrm{pH}$ meter, calibrated with a buffer of $\mathrm{pH} 4$ and $\mathrm{pH} 7$ (AOAC 2012). The total LAB was measured based on Roberts and Greenwood (2003). Titrable acidity (total lactic acid) was measured by mixing 10 gr of yogurt sample with $30 \mathrm{~mL}$ of distilled water. It was calculated with $0.1 \mathrm{~N} \mathrm{NaOH}$ using phenolphthalein indicator until it showed pink color (Matela et al. 2019). The total solid content was measured by Official Methods of Analysis AOAC (2012). Total LAB was expressed in $\log \mathrm{CFU} / \mathrm{mL}$.

\section{Data Analysis}

Probiotics Properties of Isolate LAB data which consisted of three replications were analyzed descriptively. Mean data of yogurt production and storage at refrigerator temperature were analyzed using analysis of variance. Data with significant influence $(\mathrm{P}<0.05)$ continued with the Duncan's Multiple Range Test using SPSS software statistic 19.

\section{RESULT AND DISCUSSION}

\section{Probiotics properties of isolate $\mathbf{L A B}$}

Characterization of K12.1 Lactic Acid Bacteria isolate as a probiotic

The results of LAB's characterization as a probiotic candidate and a potential bio-preservation producer can be seen in the data recapitulation in Table 1.

One of the important factors for survival in the digestive tract is the ability to compete with pathogenic bacteria in the intestine and is expressed by producing various antimicrobial compounds in the host (Salminen et al. 1998). Cell-free supernatant from K12.1 has inhibitory activity against the growth of $E$. coli O157: H7, L. monocytogenes, S. aureus ATCC 25923. Cell-free supernatants had different abilities to inhibit the growth of pathogenic bacteria. The highest inhibition of this antimicrobial was seen in Listeria monocytogenes CFSAN004330. Pan et al. (2009) stated that a high level of antimicrobial activity was detected if the diameter of the zone of inhibition was more than $6 \mathrm{~mm}$. Several $L$. plantarum had been known to produce bacteriocins, called plantaricin, which have antimicrobial activity against pathogenic bacteria, such as L. plantarum LR/14 (Tiwari and Srivastava 2008) and L. plantarum A-1 isolated from tortillas (Hata et al. 2010).
One of the conditions for obtaining the benefits of LAB probiotics was that they could survive in the digestive tract, including stomach acid and bile salts. The observations of the viability of the K12.1 LAB isolate grown on MRS-B media with the addition of $\mathrm{HCl}(\mathrm{pH} 2$ and 3) for $90 \mathrm{~min}$ were 96.74 and $99.10 \%$, respectively. The viability of LAB isolates in this study was greater than $90 \%$. This shows that LAB isolates can survive after incubation for $90 \mathrm{~min}$ at $\mathrm{pH}$ 2 and 3 and are potential candidates for probiotics, which are expected to survive until the large intestine, following the opinion of Cheow and Hadinoto (2013), which explains that one of the criteria for $\mathrm{LAB}$ as a probiotic was that LAB must be able to withstand acidic conditions, with estimated viability of equal to or more than $50 \%$.

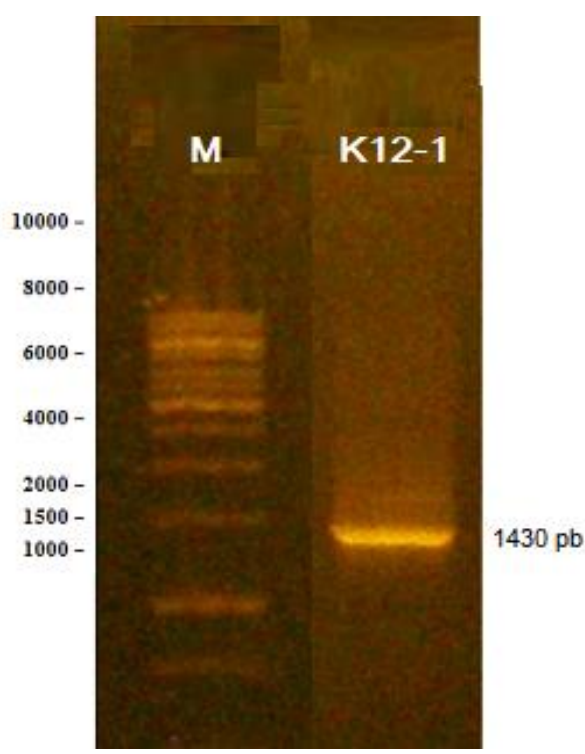

Figure 1. PCR electrophoresis product of K12.1 Lactic Acid Bacteria isolate

Table 1. Probiotics characteristic of K12.1 Lactic Acid Bacteria isolate

\begin{tabular}{lc}
\hline \multicolumn{1}{c}{ Probiotic characteristics } & Value \\
\hline Antimicrobial against (inhibition zone mm) & \\
E. coli 0157:H7 & $7.48 \pm 0.07$ \\
S. aureus ATCC 25923 & $11.73 \pm 0.15$ \\
L. monocytogenes CFSAN004330 & $19.51 \pm 0.05$ \\
Viability in acidic conditions (pH 2) 90 min (\%) & $96.74 \pm 0.06$ \\
Viability in acidic conditions (pH 3) 90 min (\%) & $99.10 \pm 0.11$ \\
Viability in bile salt conditions 0.3\% 5 hours (\%) & $98.20 \pm 0.09$ \\
Viability in bile salt conditions 0.5\% 5 hours (\%) & $96.22 \pm 0.10$ \\
Hydropobicity (\%) & $51.93 \pm 0.04$ \\
\hline
\end{tabular}

Note: The values were expressed as the mean \pm standard deviation $(n=4$ 


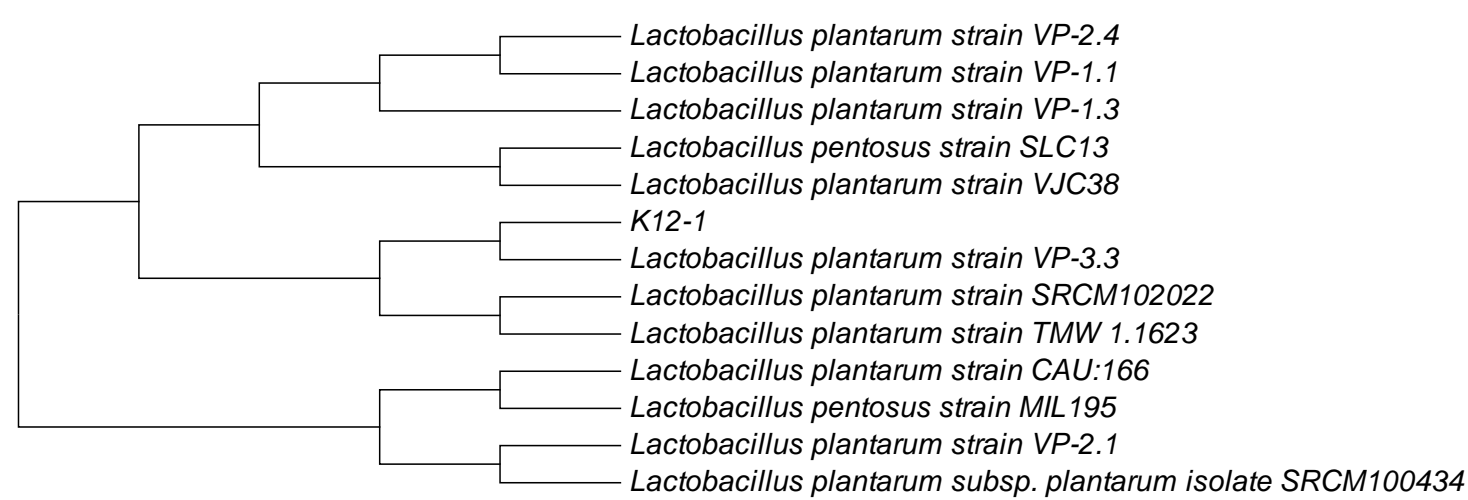

Figure 2. Phylogenetic K12.1 isolate of Lactic Acid Bacteria

To ensure optimum functionality and expression of health-promoting physiological functions by probiotics, survivability and colonization in the digestive tract were considered critical. From Table 1, it could be seen that the high viability of LAB was at 0.3 and $0.5 \%$ oxgall. This data showed only a slight decrease in the amount of LAB in the medium containing oxgall. This decrease in viability was since bile was an active compound, which can react with the cell membrane's lipolytic surface. The active nature of bile causes the lipolytic enzymes to react with the fat in the cell membrane. This condition affects the permeability of the cell membrane and will eventually cause cell lysis. According to Majeed et al. (2019) LAB, resistance to bile salts was related to the bile salt hydrolase enzyme, which helps hydrolyze de-conjugated bile salts, reduces toxic effects on bacterial cells, and can lower cholesterol. Based on the results of previous research Tokatli et al. (2015) and Rossi et al. (2018) showed that probiotics were LAB that was resistant to stomach acid and bile salts.

\section{Identification K12.1 Lactic Acid Bacteria isolates using $16 S$ rRNA.}

In Figure 1, it can be seen that the amplification of the area of the 16S rRNA gene isolates Lactic Acid Bacteria from solid waste of making soy milk. It can be seen by the appearance of PCR fragment of size $1430 \mathrm{pb}$ using the universal primers $27 \mathrm{~F}$ (5'-GAGTTTGATCCTGGCCTAG3 '), 1525 R (5'-AGAAAGGAGGTGATCCAGCC-3'). Phylogenetic trees based on 16S rRNA gene sequence analysis can be seen in Figure 2. Sequencing results of K12.1 isolates compared to Gene Bank data using the BLAST program on the NCBI website showed a similarity rate of $99.9 \%$ with Lactobacillus plantarum VP-3.3.

\section{Yogurt production using microencapsulation inoculum} Physicochemical and microbiology properties of yogurt

Table 2 shows that the $\mathrm{pH}$ of yogurt in treatment $\mathrm{P} 4$ (7\% inoculum) was significantly different $(\mathrm{P}<0.05)$ compared to the $\mathrm{pH}$ in treatment $\mathrm{P} 1, \mathrm{P} 2$, and $\mathrm{P} 3$ were inoculum concentrations of 1,3 and $5 \%$, respectively. The
P3 and P4 yogurt samples' pH complied with the Food and Drug Administration (FDA) specifications, stating that yogurt must have a maximum $\mathrm{pH}$ of 4.5 (Weerathilake et al. 2014). In treatment $\mathrm{P} 1$ and $\mathrm{P} 2$, the $\mathrm{pH}$ of yogurt did not meet the FDA requirements. This was due to the 1 and 3\% of income used for treatment $\mathrm{P} 1$ and $\mathrm{P} 2$, respectively. This small amount of inoculum causes the lactase enzyme produced to be insufficient to ferment all available lactate into lactic acid. Similar results were found El-Kholy et al. (2020), which determines the $\mathrm{pH}$ of low-fat yogurt containing inulin for 1,7 , and 14 day storage periods, respectively, were $4.54,4,38$, and 4.22 . The $\mathrm{pH}$ value describes the amount of lactic acid produced from lactose fermentation by LAB (Oladipo et al. 2014). The results showed that the average $\mathrm{pH}$ value of yogurt was comparable to that stated by Ahmad et al. (2020), who studied the effect of fortification of apple skin polyphenol extract on probiotic characteristics yogurt with the highest $\mathrm{pH}$ of yogurt was 4.56 on the first day of storage. The lowest $\mathrm{pH}$ of yogurt was 4.02 on the 21 st day of storage. The $\mathrm{pH}$ of yogurt is also in line with ul Haq et al. (2019) research on the development and evaluation of yogurt with lentil flour where its $\mathrm{pH}$ was decreased from 4.50, 4.33, $4.27,4.15$, and 4.05 for $1,7,14,21$, and 28 yogurt samples respectively.

Titratable acidity was expressed as a percentage of total lactic acid formed during lactose fermentation by LAB. The average total value of yogurt lactic acid can be seen in Table 2. The percentage of titratable acidity was $0.63,0.74$, 0.85 , and $0.99 \%$, respectively, for $\mathrm{P} 1, \mathrm{P} 2, \mathrm{P} 3$, and $\mathrm{P} 4$. Compared to other samples, samples P3 and P4 had extremely high titratable acidity, which may be attributed to the greater availability of microbes used for fermentation. Tamime and Robinson (2007) stated that LAB's ability to produce acid varies depending on the species, the level of the inoculum, the state, and the composition of the growth media. Only P4 complied with the FDA specification among these four treatments, which specifies that yoghurt should have a minimum titratable acidity of 0.9 percent (Weerathilake et al. 2014). 
Table 2. Physicochemical and microbiology properties of yoghurt

\begin{tabular}{|c|c|c|c|c|c|}
\hline \multirow{2}{*}{ Yogurt characteristics } & \multirow{2}{*}{ SNI* 2981:2009 yoghurt } & \multicolumn{4}{|c|}{ Microencapsulation starter (v/v) } \\
\hline & & $P_{1}=1 \%$ & $\mathbf{P}_{2}=3 \%$ & $\mathbf{P}_{3}=5 \%$ & $P_{4}=7 \%$ \\
\hline $\mathrm{pH}$ & & $4.59^{\mathrm{d}} \pm 0.013$ & $4.48^{c} \pm 0.010$ & $4.42^{\mathrm{b}} \pm 0.014$ & $4.36^{\mathrm{a}} \pm 0.047$ \\
\hline Titrable acidity $(\%)$ & $0.5-2.0$ & $0.63^{\mathrm{a}} \pm 0.073$ & $0.74^{b} \pm 0.086$ & $0.85^{\mathrm{c}} \pm 0.052$ & $0.99^{\mathrm{d}} \pm 0.073$ \\
\hline Total Solid (\%) & Min. 8.2 & $9.63^{\mathrm{a}} \pm 0.170$ & $9.82^{\mathrm{a}} \pm 0.464$ & $9.97^{\mathrm{ab}} \pm 0.334$ & $10.40^{\mathrm{b}} \pm 0.227$ \\
\hline Viscosity $(\mathrm{cP})$ & & $423.22^{\mathrm{a}} \pm 1.965$ & $438.35^{\mathrm{a}} \pm 1.380$ & $533.47^{\mathrm{b}} \pm 2.012$ & $546.37^{\mathrm{b}} \pm 1.694$ \\
\hline $\begin{array}{l}\text { Total Lactic Acid Bacteria } \\
(\text { LogCFU } / \mathrm{mL})\end{array}$ & $\operatorname{Min} 7 / 10^{7}(\mathrm{col} / \mathrm{g})$ & $9.69^{\mathrm{a}} \pm 0.056$ & $9,83^{\mathrm{a}} \pm 0.062$ & $9.99^{\mathrm{b}} \pm 0.051$ & $10.08^{\mathrm{b}} \pm 0.037$ \\
\hline
\end{tabular}

Note: Values followed by different superscripts in the same row were significantly different $(\mathrm{p}<0.05)$. The value was expressed in mean \pm standard deviation $(\mathrm{n}=4)$. *SNI: Standar Nasional Indonesia (Indonesian National Standard

Tabel 3. pH, total Lactic Acid Bacteria count, and viability of Lactic Acid Bacteria

\begin{tabular}{cccc}
\hline Storage time (days) & $\mathbf{p H}$ & Total LAB $(\mathbf{l o g}$ CFU/mL) & LAB Viability $(\%)$ \\
\hline 0 & $4.36^{\mathrm{a}} \pm 0.047$ & $10.08^{\mathrm{c}} \pm 0.037$ & $100.00 \pm 0.000$ \\
7 & $4.33^{\mathrm{ab}} \pm 0.033$ & $10.05^{\mathrm{ac}} \pm 0.039$ & $99.66 \pm 0.388$ \\
14 & $4.29^{\mathrm{b}} \pm 0.021$ & $10.03^{\mathrm{abc}} \pm 0.041$ & $99.51 \pm 0.407$ \\
21 & $4.27^{\mathrm{b}} \pm 0.013$ & $10.00^{\mathrm{ab}} \pm 0.035$ & $99.17 \pm 0.351$ \\
28 & $4.20^{\mathrm{c}} \pm 0.016$ & $9.98^{\mathrm{a}} \pm 0.041$ & $99.04 \pm 0.405$ \\
\hline
\end{tabular}

Note: Values followed by different superscripts in the same row were significantly different $(\mathrm{p}<0.05)$. Value was expressed in mean \pm standard deviation $(\mathrm{n}=4)$

The use of different inoculum levels for yogurt production had a significant impact $(\mathrm{P}<0.05)$ on the total solids of yogurt (Table 2). The highest total solid was $10.40 \%$ at $\mathrm{P} 4$ treatment, using $7 \%$ inoculum. The use of $7 \%$ inoculum as a starter yogurt causes the fermentation process to run well, characterized by decreased $\mathrm{pH}$. A decrease in $\mathrm{pH}$ value indicates an increase in lactic acid production and total $\mathrm{LAB}$, as seen in the $\mathrm{P} 4$ treatment with the highest total solid content. This total solid content affects the viscosity of yogurt. In this study, the highest total solids and viscosity were obtained in the P4 treatment, respectively $10.40 \%$ and $546.37 \mathrm{cP}$. Yogurt's viscosity is influenced by the total solid content of milk, heat treatment, and incubation temperature (Lee and Lucey 2010). Viscosity was also influenced by $\mathrm{pH}$, where low $\mathrm{pH}$ causes milk protein (casein) to coagulate.

The LAB bacteria of the yogurt sample ranged from 9.69-10.00 $\log \mathrm{CFU} / \mathrm{mL}$. Table 2 showed that using different amounts of starters in making yogurt had a significant effect $(\mathrm{P}<0.05)$ on the total LAB content. Total LAB in treatment $\mathrm{P} 3$ and $\mathrm{P} 4$ was significantly different (P $<0.05)$ with $\mathrm{P} 1$ and $\mathrm{P} 2$ treatment. The high LAB in P3 and $\mathrm{P} 4$ was due to the two treatments using more starter than P1 and P2. This illustrates that the nutrient content contained in the medium is still sufficient for the growth of $\mathrm{LAB}$ in $\mathrm{P} 3$ and $\mathrm{P} 4$ using a starter of $5 \%$ to $7 \%$. The total number of $\mathrm{LAB}$ in all treatments fulfilled the number of LAB requirements for probiotics $\left(10^{6}-10^{7} \mathrm{CFU} / \mathrm{mL}\right.$ that reached the colon (Castro et al. 2015).

Change of $\mathrm{pH}$ and total Lactic Acid Bacteria count and their viability during storage at $4^{\circ} \mathrm{C}$ for 28 days

The $\mathrm{pH}$ of yogurt changed during the incubation and storage period due to biochemistry and microbial growth changes. Statistical data showed that the $\mathrm{pH}$ of yogurt samples at 28 days of storage was significantly different ( $\mathrm{p}$ $<0.05$ ) from the $\mathrm{pH}$ of yogurt samples at other storage times (Table 3). During yogurt storage, the decrease in $\mathrm{pH}$ was due to the increased activity of $L$. plantarum strain $V P-3.3$ and $S$. thermophilus, the inoculum for yogurt production. The fermentation was still running at $4^{\circ} \mathrm{C}$, which was indicated by a decrease in $\mathrm{pH}$ to 4.2. This study's results were in line with Melia et al. (2020). There was a decrease in the $\mathrm{pH}$ of fermented goat milk from 4.48 to 4.28 using Pediococcus acidilactici was stored for up to $28 \mathrm{~d}$ at refrigerator temperature. Decreasing this $\mathrm{pH}$ showed that LAB's lactic acid was still released during storage time that fermented milk lactose. LAB fermented lactose into glucose and galactose, then converted glucose into lactic acid (Tamime and Robinson 2007). All of the yogurt samples had $\mathrm{pH}$ levels within FDA guidelines, stating that yogurt should have a maximum $\mathrm{pH}$ of 4.5 (FDA 2013). The decrease in yogurt's pH also occurred during storage for 28 days at $4^{\circ} \mathrm{C}$ (Sarwar et al. 2019). Calcium can be converted to its ionic form in yogurt due to its low $\mathrm{pH}$, rendering it highly bioavailable for intestinal absorption. The low $\mathrm{pH}$ value of yogurt will also minimize dietary phytic acid's inhibitory effect on calcium bioavailability (Adolfsson et al. 2004).

During the storage period, the total LAB varied from 9.98 to $10.08 \log \mathrm{CFU} / \mathrm{mL}$. Both LAB fermented lactose into lactic acid. The total amount of LAB decreased significantly after 14 days of cold storage at $5^{\circ} \mathrm{C}$. This decreasing total LAB was due to the limited nutrition in the yogurt because most of the nutrients had been used during the fermentation and storage processes. Another cause might be that secondary metabolic substances had begun to be produced, such as bacteriocins, which have 
antimicrobial activity. This result was also in line with the research of (Melia et al. 2020), which produced fermented goat milk and the total LAB decreased at storage for up to 28 days $(9,106 \log$ CFU/mL). Karami (2018) reported that the amount of Lactobacillus bulgaricus and Streptococcus thermophilus in both ewe and cow milk yogurt decreased significantly after 15 days of cold storage $5^{\circ} \mathrm{C}$. Terpou et al. (2017) also reported that a decrease in bacterial cells occurred after 30 days of storage.

The viability of LAB during storage decreased not significantly $(\mathrm{P}>0.05)$. The viability of $\mathrm{LAB}$ at each observation time ranges from $99-100 \%$. If the viability of probiotic bacteria was at a high level, health benefits were achieved. The amount of LAB as a probiotic is usually $10^{7}$ $10^{8} \mathrm{CFU} / \mathrm{g}$. A decrease in the CFU amount below the range (107-108 CFU/g) decreases the desired pharmacological activity (Patil et al. 2019). This relatively high viability was due to one of the cultures used was L. plantarum strain VP3.3, which was selected as LAB as probiotic characteristics (Table 1). Besides, sago starch and WIP through microencapsulation could protect LAB during fermentation and storage at refrigerated temperatures. These results were also confirmed in the LAB microencapsulation study by (De Prisco et al. 2017) that starter culture microencapsulation in making yogurt can increase LAB's viability, thereby improving its quality yogurt.

In conclusion, based on the molecular identification results with $16 \mathrm{~S}$ rRNA, the K12.1 isolate with probiotic characteristics was L. plantarum strain VP-3.3. The microencapsulation starter concentration affects acidity, total acid, total LAB, viscosity, and total solids. The use of $7 \%$ microencapsulation starter of $L$. plantarum strain VP3.3 and $S$. thermophilus gave the best yogurt, with a $\mathrm{pH}$ value of 4.36 , total lactic acid $0.99 \%$, total LAB $10.00 \log$ CFU/mL, viscosity $546.37 \mathrm{cP}$, and total solids $10.40 \%$. Yogurt storage at cold temperatures for 28 days can still sustain the amount of LAB meeting the probiotic requirement of $9.7 \log \mathrm{CFU} / \mathrm{mL}$ with a yogurt $\mathrm{pH}$ of 4.20 that still complies with the Indonesian National Standard of yogurt (No. 2981: 2009). The use of sago starch and whey protein isolate as microencapsulation materials maintained LAB viability in yogurt during storage for up to 28 days at $4{ }^{\circ} \mathrm{C}$ above $99 \%$.

\section{ACKNOWLEDGEMENTS}

The authors wish to thank Riau University, Indonesia for funding this research. This research's funding source is DIPA LPPM University Riau in 2020 with contract number: 791/UN19.5.1.3/PT.01.03/2020.

\section{REFERENCES}

Adolfsson O, Meydani MS, Russell MR. 2004. Yogurt and gut function. Am J Clin Nutr 80: 245-256. DOI: 10.1093/ajcn/80.2.245.

Ahmad I, Khalique A, Shahid MQ, Rashid AA, Faiz F, Ikram MA, Ahmed S, Imran M, Khan MA, Nadeem M, Afzal MI, Umer M, Imdad K, Shahbaz M, Rasool B. 2020. Studying the influence of apple peel polyphenol extract fortification on the characteristics of probiotic yoghurt. Plants 91: 1-15. DOI: 103390/plants9010077.
Aritonang SN, Roza E, Rossi E. 2019. The effect of whippy cream adding on the quality of frozen soyghurt as symbiotic ice cream. IOP Conf Ser: Earth Environ Sci 287 (1). DOI: 101088/17551315/287/1/012029.

Aritonang SN, Roza E, Rossi E, Purwati E, Husmaini. 2017. Isolation and identification of Lactic Acid Bacteria from okara and evaluation of their potential as candidate probiotics. Pak J Nutr 168: 618-628. DOI: $103923 /$ pjn2017618628.

Castro JM, Tornadijo ME, Fresno JM, Sandoval H. 2015. Biocheese: A food probiotic carrier. BioMed Res Intl 2015: 1-11. DOI: 101155/2015/723056.

Cheow WS, Hadinoto K. 2013. Biofilm-like Lactobacillus rhamnosus probiotics encapsulated in alginate and carrageenan microcapsules exhibiting enhanced thermotolerance and freeze-drying resistance. Biomacromolecules 149: 3214-3222. DOI: 101021/bm400853d.

Collado MC, Gueimonde M, Sanz Y, Salminen S. 2006. Adhesion properties and competitive pathogen exclusion ability of bifidobacteria with acquired acid resistance. J Food Prot 697: 16751679. DOI: 104315/0362-028X-6971675.

Collado MC, Surono I, Meriluoto J, Salminen S. 2007. Indigenous dadih Lactic Acid Bacteria: Cell-surface properties and interactions with pathogens. J Food Sci 72 (3): M89-83. DOI: 101111/j17503841200700294x.

De Prisco A, van Valenberg, HJF, Fogliano V, Mauriello G. 2017. Microencapsulated starter culture during yoghurt manufacturing, effect on technological features. Food Bioprocess Technol 10 (10): 1767-1777. DOI: 10.1007/s11947-017-1946-8.

Del Re B, Sgorbati B, Miglioli M, Palenzona D. 2000. Adhesion autoaggregation and hydrophobicity of 13 strains of Bifidobacterium longum. Lett Appl Microbiol 31 (6): 438-442. DOI: 101046/j13652672200000845x.

Desmond C, Ross RP, O’Callaghan E, Fitzgerald G, Stanton C. 2002. Improved survival of Lactobacillus paracasei NFBC 338 in spraydried powders containing gum acacia. J Appl Microbiol 93 (6): 10031011. DOI: 101046/j1365-2672200201782x.

Donkor ON, Henriksson A, Vasiljevic T, Shah NP. 2006. Effect of acidification on the activity of probiotics in yoghurt during cold storage. Intl Dairy J 16 (10): 1181-1189. DOI: 101016/jidairyj200510008.

Donkor ON, Nilmini SLI, Stolic P, Vasiljevic T, Shah NP. 2007. Survival and activity of selected probiotic organisms in set-type yoghurt during cold storage. Int Dairy J 17 (6): 657-665. DOI: 101016/jidairyj200608006.

El-Kholy WM, Aamer RA, Ali AN. 2020. Utilization of inulin extracted from chicory Cichorium intybus L roots to improve the properties of low-fat synbiotic yoghurt. Ann Agric Sci 65 (1): 59-67. DOI: 101016/jaoas202002002.

FDA. 2013. Yoghurt 21 CFR 131200 code of federal Regulation US Dept of Health and Human Services, Washington, DC.

Hata T, Tanaka R, Ohmomo S. 2010. Isolation and characterization of plantaricin ASM1: A new bacteriocin produced by Lactobacillus plantarum A-1. Int J Food Microbiol 137 (1): 94-99. DOI: 101016/jijfoodmicro200910021.

Hawaz E. 2014. Isolation and identification of probiotic Lactic Acid Bacteria from curd and in vitro evaluation of its growth inhibition activities against pathogenic bacteria. Afr J Microbiol Res 8 (13): 1419-1425. DOI: 10.5897/AJMR2014.6639.

Howarth GS, Wang H. 2013. Role of endogenous microbiota probiotics and their biological products in human health. Nutrients 5 (1): 58-81. DOI: 103390/nu5010058.

Hugo AA, Kakisu E, De Antoni GL, Pérez PF. 2008. Lactobacilli antagonize biological effects of enterohaemorrhagic Escherichia coli in vitro. Lett Appl Microbiol 46 (6): 613-619. DOI: 101111/j1472765X200802363x

Karami M. 2018. Investigation of physicochemical microbiological and rheological properties and volatile compounds of ewe and cow milk yoghurt. J Agric Sci Technol 20 (6): 1149-1160.

Kassaian N, Feizi A, Aminorroaya A, Amini M. 2019. Probiotic and synbiotic supplementation could improve metabolic syndrome in prediabetic adults: A randomized controlled trial Diabetes and Metabolic Syndrome. Clin Res Rev 13 (5): 2991-2996. DOI: 101016/jdsx201807016.

Lee WJ, Lucey JA. 2010. Formation and physical properties of yogurt Asian-Australasian. J Anim Sci 23 (9): 1127-1136. DOI: 105713/ajas2010r05 
Majeed M, Majeed S, Nagabhushanam K, Arumugam S, Beede K, Ali F. 2019. Evaluation of the in vitro cholesterol-lowering activity of the probiotic strain Bacillus coagulans MTCC 5856. Intl J Food Sci Technol 54 (1): 212-220. DOI: 101111/ijfs13926.

Maleki O, Khaledabad MA, Amiri S, Asl AK, Makouie S. 2020. Microencapsulation of Lactobacillus rhamnosus ATCC 7469 in whey protein isolate-crystalline nanocellulose-inulin composite enhanced gastrointestinal survivability. LWT 126: 109224. DOI: 101016/jlwt2020109224.

Matela KS, Pillai MK, Thamae T. 2019. Evaluation of pH titratable acidity syneresis and sensory profiles of some yoghurt samples from the kingdom of Lesotho. Food Res 3 (6): 693-697. DOI: 1026656/fr201736177

Melia S, Juliyarsi I, Kurnia YF, Pratama YE, Pratama DR. 2020. The quality of fermented goat milk produced by Pediococcus acidilactici $B K 01$ on refrigerator temperature. Biodiversitas 21 (10): 4591-4596. DOI: $1013057 /$ biodiv/d211017.

Oladipo IC, Atolagbe OO, Adetiba TM. 2014. Nutritional evaluation and microbiological analysis of yoghurt produced from full cream milk tiger-nut milk skimmed milk and fresh cow milk. Pensee J 76 (4): 3038.

Öz E, Kaban G, Barış Ö, Kaya M. 2017. Isolation and identification of Lactic Acid Bacteria from pastırma. Food Control 77: 158-162. DOI: 10.1016/j.foodcont.2017.02.017

Pan X, Chen F, Wu T, Tang H, Zhao Z. 2009. The acid bile tolerance and antimicrobial property of Lactobacillus acidophilus NIT. Food Control 20 (6): 598-602. DOI: 101016/JFOODCONT200808019.

Rajam R, Karthik P, Parthasarathi S, Joseph GS, Anandharamakrishnan C. 2012. Effect of whey protein - alginate wall systems on survival of microencapsulated Lactobacillus plantarum in simulated gastrointestinal conditions. J Funct Foods 4 (4): 891-898. DOI: 101016/jjff201206006

Roberts D, Greenwood M. 2003. Practical Food Microbiology. Blackwell Publishing Ltd., New York. DOI: 10.1002/9780470757512

Rossi E. 2018. Potential isolate of Lactic Acid Bacteria from solid waste making soybean milk as a probiotic and natural preservative in functional food. [Dissertation] Graduate School, Universitas Andalas, Padang. [Indonesian]

Rossi E, Roza E, Sofyan Y, Aritonang SN, Purwati E. 2018 Characterization of probiotics properties of lactobacillus from solid waste of soy milk production. Asian J Microbiol Biotechnol Environ 20 (3): 18-23.

Salminen S, Bouley C, Boutron MC, Cummings JH, Franck A, Gibson GR, Isolauri E, Moreau MC, Roberfroid M, Rowland I. 1998 Functional food science and gastrointestinal physiology and function. Br J Nutr 80 (S1): S147-S171. DOI: 101079/bjn19980108.

Salminen S, Wright AV. 2011 Probiotics: Safety and Efficacy. In: Lactic Acid Bacteria: Microbiological and Functional Aspects. CRC Press, Boca Raton, FL.

Sánchez-Ortiz A, Luna-González A. 2015. Isolation and characterization of potential probiotic bacteria from pustulose ark Anadara tuberculosa suitable for shrimp farming. Latin Am J Aquat Res 43 (1): 123-136. DOI: 10.3856/vol43-issue1-fulltext-11.

Sarwar A, Aziz T, Al-Dalali S, Zhao X, Zhang J, Ud Din J, Chen C, Cao Y, Yang Z. 2019. Physicochemical and microbiological properties of synbiotic yogurt made with probiotic yeast Saccharomyces boulardii in combination with inulin. Foods 8 (10): 1-18. DOI: 103390/foods 8100468 .

Shi LE, Li ZH, Li DT, Xu M, Chen HY, Zhang ZL, Tang ZX. 2013. Encapsulation of probiotic Lactobacillus bulgaricus in alginate milk microspheres and evaluation of the survival in simulated gastrointestinal conditions. J Food Eng 117 (1): 99-104. DOI: 101016/jjfoodeng201302012.

Shi T, Nishiyama K, Nakamata K, Aryantini N, P S, Mikumo D, Oda Y, Yamamoto Y, Mukai T, Sujaya IN, Urashima T, Fukuda K. 2012. Isolation of potential probiotic Lactobacillus rhamnosus strains from traditional fermented mare milk produced in Sumbawa Island of Indonesia. Biosci Biotechnol Biochem 76 (10): 1897-1903. DOI: $101271 /$ bbb120385.

Tadesse G, Ephraim E, Ashenafi M. 2005. Assessment of the antimicrobial activity of Lactic Acid Bacteria isolated from Borde and Shamita traditional Ethiopian fermented beverages on some foodborne. J Food Saf 5: 13-20.

Tamime A, Robinson R. 2007. Yogurt Science and Technology. Woodhead Publishing Limited, Abington.

Tamime AY, Saarela MA, KS Sondergaard AK, Mistry VV, Shah NP. 2005. Probiotic Dairy Products. DOI: 101002/9780470995785.

Terpou A, Gialleli AI, Bekatorou A, Dimitrellou D, Ganatsios V, Barouni E, Koutinas AA, Kanellaki M. 2017. Sour milk production by wheat bran-supported probiotic biocatalyst as starter culture. Food Bioprod Process 101: 184-192. DOI: 101016/jfbp201611007.

Tiwari SK, Srivastava S. 2008. Purification and characterization of plantaricin LR14: a novel bacteriocin produced by Lactobacillus plantarum LR/14. Appl Microbiol Biotechnol 79: 759-767. DOI: 10.1007/s00253-008-1482-6.

Tokatli M, Gülgör G, Bałder, Elmac S, Arslankoz IN, Özçelik F. 2015. In vitro properties of potential probiotic indigenous Lactic Acid Bacteria originating from traditional pickles. BioMed Res Intl 2015: 1-8. DOI: $101155 / 2015 / 315819$.

ul Haq F, Sameen A, u Zaman Q, Mushtaq BS, Hussain MB, Javed A, Plygun S, Korneeva O, Shariati MA. 2019. Development and evaluation of yogurt supplemented with lentil flour. J Microbiol Biotechnol Food Sci 8 (4): 1005-1009. DOI: 1015414/jmbfs2019841005-1009.

Vamadevan V, Bertoft E, Seetharaman K. 2013. On the importance of organization of glucan chains on thermal properties of starch. $\begin{array}{lllll}\text { Carbohydr } & \text { Polym } & 92 & \text { (2): } & \text { 1653-1659. }\end{array}$ 101016/jcarbpol201211003.

Vasile MA, Milea, Stefania A, Enachi E, Barbu V, Cîrciumaru A, Bahrim GE, Râpeanu G, Stănciuc N. 2020. Functional Enhancement of bioactives from black beans and Lactic Acid Bacteria into an innovative food ingredient by comicroencapsulation. Food Bioprocess Technol 13: 978-987. DOI: 101007/s1 1947-020-02451-8.

Vidhyalakshmi R, Bhakyaraj R, Subhasree RS. 2009. Encapsulation "The Future of Probiotics"-A Review. Adv Biol Res 3 (3-4): 96-103.

Vitiñi E, Alvarez S, Medina M, Medici M, De Budeguer MV, Perdigón G. 2000. Gut mucosal immunostimulation by Lactic Acid Bacteria. Biocell 24 (3): 223-232.

Weerathilake WADV, Rasika DMD, Ruwanmali JKU, Munasinghe MADD. 2014. The evolution processing varieties and health benefits of yogurt. Int J Sci Res Publ 4 (1): 2250-3153.

Yang E, Fan L, Jiang Y, Doucette C, Fillmore S. 2012. Antimicrobial activity of bacteriocin-producing Lactic Acid Bacteria isolated from cheeses and yogurts. AMB Expr 2 (1): 1-12. DOI: 101186/21910855-2-48.

Yelnetty A, Purwadi, Tallei TE. 2020. Indigenous Lactic Acid Bacteria isolated from spontaneously fermented goat milk as potential probiotics. Pak J Biol Sci 23 (7): 883-890. DOI: 103923/pjbs2020883890.

Zhu F. 2019. Recent advances in modifications and applications of sago starch. Food Hydrocoll 96: 412-423. DOI: 101016/jfoodhyd201905035. 